Irena Teodora VESEVSKA

UDK: 316.663-055.2:27"652"

Original research paper

\title{
WOMEN IN LATE ANTIQUITY AND EARLY CHRISTIANITY: THE VOICES AND DEEDS OF THE "SILENT" MINORITY
}

\begin{abstract}
The status of women in Late Antiquity and early Christianity has been an inspiring theme for debate in the last few decades. The New Testament is full of texts that testify about the involvement of women in early Christian communities. In the Epistles of St. Paul, he salutes women, addresses them as collaborators, one of them as the deaconess, and even calls one the Apostle. This text makes a brief overview of the role and position of women in antiquity, which, in addition to the later analysis of their place in the early Christian world, will best show whether and how much the new religion influenced their, to use here an exquisite modern word, emancipation. In the context of this, we are also going to study several examples of deciduous mosaics from archaeological sites in the Republic of Macedonia.
\end{abstract}

DANTS.

Key words: WOMEN, LATE ANTIQUE, EARLY CHRISTIANITY, MOSAIC DESCEN-

\section{Introduction}

The question of the place and role of the woman in Late Antiquity and early Christianity has so far been analyzed from various aspects. Bearing in mind the consistent methodology and research persistence, one gets the impression that there has not yet been a general and complete review of the role of the woman in the Bible world and the Bible environment. In some of these studies some, and sometimes many, things are missing; mostly because of ideological prejudices, and often because of the modest and inadequate knowledge of matter, as well as the historical - social context and the religious environment from which it originated. However, in the last two decades, the history of women in early Christianity has been almost completely revised: the search for a female presence in previously neglected texts or new findings through the search for new responses and the use of a different methodology already yields fruit. But how much did the social role and status of women change with Christianity? Before attempting to give a detailed answer to this question, we should look at the role and status of women in ancient societies. 


\section{Ancient Greece}

Athens laid the foundations of a formalized approach to women as a man-made, predisposed and projected humiliating attitude that we can follow back to Homer. ${ }^{1}$ Socrates, as Plato declares in the "Republic", although against the division of responsibilities between sexes, points out that in every work the woman is weaker than the man (Plato, 1956). For Socrates' disciple Xenophon, the ideal woman is the one who sees as little as possible, is as silent as possible and asks even less (Xenophon, 625). Aristotle devotes a significant place to the family, that is, to the woman, who he sees in a subordinate position in relation to the man, that is, the human. For example, the second - degree role of the woman is obvious, which arises primarily from his understanding of a society in which a woman has no formal role. Since the life of the political state is the peak of social life and by nature is more superior to the family, it is understood that men have the advantage of organizing the political life and the participation in it. (Aristotle, Politics 1, 2,1259a-b)

It is interesting to note that Aristotle in the designing of his state was largely inspired by the organization of the bees, more precisely the queen, which is so organized in the task of the honey bees, which for Aristotelian consciousness, as well as for the entire then general context, was unthinkable that this flagship is not a male, so he calls her the King of Bees ( $\beta \alpha \sigma i \lambda \varepsilon \varsigma \varsigma)$.

While Aristotle explores the place and role of women within the state and the general social - political philosophy; his contemporary Demosthenes, a speaker and thinker, speaks about the same issues in everyday life:

We have courtesans for our pleasure, prostitutes young female slaves) for everyday physical use, wives to give birth to our legitimate children and to be faithful housewives in domestic affairs. (Demosthenes, 59, 122)

Although women lived retreated, in the home circle and did the houseworks, especially in the classical world, it is evident that after the 3rd century BC, they begin to move in wider social circles. A certain number of women received primary education, which in this case involved: athletics, musical knowledge and reading (Pomeroy, 137). Although there are examples of women involved in philosophy ${ }^{2}$, these examples were rare and the participation of women in such schools did not mean that they did not have a humiliating and disdainful attitude towards women.

\footnotetext{
${ }^{1}$ For example: "nothing worthy of trust in the woman", Odyssey II, 456; or the words by which the inexperienced Telemachus addresses her mother Penelope "Go into your own chambers and deal with your affairs, (...) I am the leader, the head of the household," Odyssey 21, 350-354.

${ }^{2}$ For example. Hipparchia, a cynics philosopher, and was often seen with her husband at public gatherings.
} 


\section{Rome}

Regarding the place and role of the woman in Rome, it is difficult to give a balanced cross-section, whether it is a free woman, a liberated maid, or a slave girl. In general, two stages can be followed: from the foundation of the Republic until the end of the 3rd and the beginning of the 2nd century BC; and from the beginning of the 2nd century BC until the fall of the Republic. The first stage is characterized by the exalted place of the family in society, whose position is legally formulated by the famous Roman lawyer Modestinus from the middle of the 3rd century BC. with the definition: marriage is the lifelong union of woman and man in all divine and human rights. (Самарџић, 54). This definition comes as a warning in a time just when marriage communities and family are losing high standards.

It is difficult to sense the true role of the woman in this process, primarily because of the lack of materials, but also because of the nature of her position in the society.

"The life of every woman was enclosed with a thick silence imposed by the outside world and the women themselves. The praises of women's virtues were regarded by the outside world as tasteless, less indecent, since her talents and abilities were only expressed in the home. " (Fraschetti, 2)

However, it was commonly known that the only virtues that a woman should possess were modesty and innocence. And those who owned them, and others, were levelled against the view that they had a weak intellect, a permissive character, and in general an impotence considered precisely for a typical female characteristic. (Beauchamp, 485-508)

The above-mentioned weakness, found in the propter sexus infirmitatem syntagma, served as the starting point for each of them and even for the legal relation to the woman. Both women and children, with male children having the advantage and most often enjoying greater affection, were under the full authority of the father - patria potestas.

Female children stayed in their father's home until their twelfth or thirteenth year when they were getting married. Until then, they had already mastered their home affairs, and very rarely received some education. Even high-school girls were deprived of formal education. By getting married, the girls crossed from the domain of the father's authority to the domain of the husband's authority, which after his death, depending on the family circumstances, could cross either to his closest family, or to her father again. (Rawson, 93-120). The difficult position of women, the privileged status of men, and the abundance of unnamed and unresolved issues in marriage and society resulted in numerous problems in marriage that usually ended in divorce. Divorce, until the Christian era, could only be requested by the husband; and infidelity of the wife (adulterium, $\mu$ oı $\chi \varepsilon i \alpha$ ) was considered as a valid reason. However, what was considered a 
woman's adultery was not always adultery in the case of a man. Namely, the relationship with a married woman from the same social layer was considered as adultery for a man, while the connection with an unmarried woman of a lower class or a liberated slave was not considered a crime of adultery but a misdeed (stuprum). In the opposite case, i.e. in the same cases when a woman was involved, everything was considered adultery. (Самарџић, 88)

\section{Judaism}

The understanding of the place and role of the woman in the mainstream of Judaism is a complex issue to which it is difficult to give a precise and short answer, above all because of the boundlessness of the subject, and because none of the authors dealing with this issue sought to give a woman's profile in Judaism, but rather tried to answer specific questions, that is, to current situations that were related to the woman. This practically functional attitude towards a woman, which is still current, left many traces in the building material that helps us put the Jewish woman in a certain and recognizable religious, social and legal context. We will try to analyse these traces analytically and synthetically and, following them, to present what is important and essential about the place and role of the woman in Judaism. All of this will help us in the next phase to see the differences that arise at the level of the New Testament more clearly.

May the man (Adam) say three blessings every day: Blessed are You, God, our Lord, King of the universe, who has not made me a non-Jew. Blessed are You, God, our Lord, King of the universe, who has not made me a woman. Blessed are You, God, our Lord, King of the universe, who has not made me a servant. .... Who has not created me a woman, because women are not obliged to fulfil the commandments. (T.Ber 7.18, 59)

There are many interpretations of this place from the Talmud, but most are characterized by superficiality. The text first puts the woman's exclusion from the full fulfilment of the commandments, which is her lack due to her biological construction, which does not always allow her to be ready to bear the joy of the whole Torah, i.e. the commandments. (Самарџић, 48)

The Jewish man (Adam), who has passed the act of bar, bar mitzvah, is not deprived of this pleasure. So, the expression Adam above all refers to an adult Jew who is given the pleasure and the blessing to always bear the whole Torah and all its commandments individually.

In cases when talking about the obligations of others to the Torah, i.e. the commandments, other terms are used, for example, woman, servant, boy, etc.

Flavius Josephus, starting from the already established understanding that the world was created and established on the hierarchical principle in which man, Adam, governs and governs the woman; adds that the woman in Judaism is always obliged to 
listen to her husband. (Flavius Josephus, 2.201). In later midrash ${ }^{3}$, the thought that one of the ten commandments (fourth) is directly addressed to Eve, reveals to her that her husband rules her, but it is not entirely clear whether that submission is the result of her sin, or the reason for it. However, female submission fits into God's cosmic order, as it was believed. However, it seems that the literature from the period of early Judaism is more anxious to portray a woman in a negative light, to emphasize her negative characteristics and inclinations, rather than to point out her subordination. Only in one single occasion is the woman given an eminent place: in the death processions, but even then because "of the woman came the beginning of sin, and through her we all die" (Самарџић, 49).

\section{Woman in early Christianity}

The New Testament Gospels, made by the last quarter of the 1st century AD, testify that women were among Jesus' first followers; his disciples Mary Magdalene, Joanna, and Susanna accompanied him in his sermons (Luke 8, 1-3); he addressed women, both publicly and solely, by learning from them (Mark 7: 24-30, Matthew 15, 21-28). Jesus was a frequent visitor to the home of Mary and Martha (Luke 10, 38-42) and had the custom of preaching and eating equally with women as well as men. ${ }^{4}$

It is Martha who first confesses that Jesus is "the Christ the Son of God" (John 11, 27), which makes it a form for all later confessors, and even more complete than the Apostle Peter himself. (Самарџић, 263). When one of his male apostles betrays him (Judah), and the other denies him (Peter), the women were those who remained firm and faithfully followed him to the cross (Mark 15, 40-41, Matthew 27, 55-56; Luke 23, 49; John 19, 25).

The Myrrhbearers on the grave were the first witnesses of the Resurrection, the first among them being Mary Magdalene. (Matthew 27, 61; Luke 24, 1-11)

These were Mary Magdalene, and Joanna, and Mary, the mother of Jacob; and others who have said this to the apostles. (Luke 24:10)

Within Christ's mission, women are equal subjects of sermons, messages, and healings. In this context, as many as 22 texts from the Gospels testify of this activity. Let's go back to the women who followed Jesus. Hengel is the first to point out that the texts of Luke (Luke 8, 1-3) and Mark (Mark 15, 40-41) show that women were a separate, autonomous group within the apostolic group. (Hengel, 243-256). These women follow Jesus in his mission, on the road from Galilee to Jerusalem. Such a bond was certainly a novelty for the then religious, social and cultural life. It was inconceivable for the Judaism of that time that the teacher had female students, or even more horrible and

\footnotetext{
${ }^{3}$ Midrash is a term that refers to a compilation of Tanak's comments

${ }^{4} \mathrm{He}$, unlike the time-being rabbis, freely and independently teaches women and is alone in their presence, which was previously considered scandalous and unacceptable (Самарџић, 257).
} 
scandalous, women who followed him around the whole country. (Самарџић, 243/4)

What is unique about the women who followed Jesus is the fact that the traditional role of hospitality and service by his female followers was seen as a way and a means to serve not only their own biological family, but also the spiritual community. The acceptance of being Jesus' disciples for them did not mean giving up traditional roles, but inspiring new meaning and importance to them, with a higher purpose and meaning (Whiterington, 118).

No one within the New Testament writings devotes as much space to women as the Apostle Paul. Historians have noticed that in antiquity there is no other document in which so many women are mentioned in the splendid section as in one of Paul's most important epistles: Romans chapter, chap. 16; as well as in the epistles to the Galatians, chap. 3; The Ephesians, ch. 5; The First Epistle to the Corinthians, ch. 7, 11 and 14; The first epistle to Timothy, ch.2 and the Second Epistle to Timothy, ch. 4.

Archaeological data that directly or indirectly testify about the place, role and involvement of the female population in the early Christian church organization on the territory of today's Republic of Macedonia are rare and hence even more valuable. Above all, the specificity of the problem requires maximum caution in the interpretation and attribution of material residues. By recognizing the weight of every attempt to clarify the true contextual placement, however, we will try to present three inscriptions that directly refer to the so-called "women's issue". These are two dedicated mosaic fields incorporated in the pavement arrangement from the first phase of the Basilica of episcope Philip in Stobi and one from the diaconicon of the southern basilica of Plaoshnik in Lychnidos. The floor in the Philip basilica is severely damaged, but according to the preserved parts and technical observations it can be concluded that all fields act as separate parts fitted into one whole.

The first inscription is derived from the northwest corner of the first mosaic decoration field, performed in the southern ship of the Basilica.

\begin{tabular}{|c|c|c|}
\hline ҮПЕР $[. . .]$. & $v \pi \varepsilon ́ \rho \varepsilon v[\chi \tilde{\eta} v]$ & because of the covenant \\
\hline 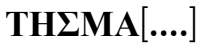 & $\tau \tilde{\eta} \varsigma \mu \alpha[\tau \rho \omega ́ \alpha \varsigma]$ & from the matron \\
\hline НЕYААВ $[. . .]$. & 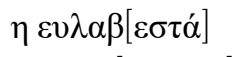 & the most religious \\
\hline ТНАIAK $[. . .]$. & $\tau \eta \delta 1 \alpha \kappa[o ́ v 1 \sigma \sigma \alpha]$ & deaconess \\
\hline THNE $\Xi[. . .]$. & $\tau \eta ́ v ~ \varepsilon ́ \xi \grave{\varepsilon} \delta \rho \alpha \nu$ & paved the exedra with mosaic \\
\hline ЕЧЕФ $\Omega[\ldots .]$. & $\dot{\varepsilon} \psi \eta \dot{\varphi} \varphi \omega[\sigma \varepsilon v]$ & \\
\hline
\end{tabular}

${ }^{5}$ Wiseman, Mano - Zissi, 397. 
The second inscription is located on the lower part of the third mosaic field incorporated in the decorative arrangement. The inscription mentions Peristeria or Peristerias as a donor of the mosaic field, although it is not explicitly indicated.

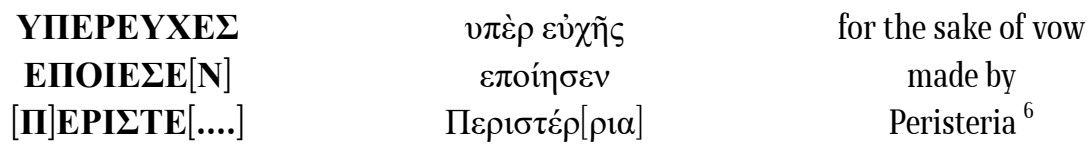

The two inscriptions do not represent an unusual tendency in their form because they belong to the huge corpus of dedicatory inscriptions found on a wider territory (Rendić-Miočević, 31-37; Цветковић - Томашевић, 32; Јанакиевски, 73, Fig.2,; Битракова - Грозданова, 52, Fig.21; Buzov, 45-64), but the relation between the donors and the chosen place for placing the mosaic is slightly unusual. Namely, if we consider the fact that all three persons mentioned on the inscriptions are women ${ }^{7}$ on the one hand, and the fact that the two inscriptions and the mosaics that follow them are placed in the southern nave of the basilica on the other hand, the question arises as to why such an "uncanonical" location was chosen.

Early Christian basilicas and temples consistently follow gender segregation, which, as we have seen, has deep roots in ancient society, and despite the revolution of "the new religion", it has been imposed in its mainstreams. In this respect, in the south (right) nave, as in the central nave, men enter, while the north (left) nave is intended for women. ${ }^{8}$

That is why the presence of these inscriptions in the southern nave is surprising.

The first phase of the mosaic decoration of the Philip Basilica, based on numismatic findings, dates back to the second or mid- ${ }^{\text {th }}$ century (Василкова - Мидоска, 48).

The questions whether this rarity is related to possible strong unorthodox doctrines that exactly during this period take a large swing throughout the Empire ${ }^{9}$, or is

\footnotetext{
${ }^{6}$ Wiseman, Mano - Zissi, 399.

${ }^{7}$ The sex of Peristeria is certainly not confirmed, since the same name is found in the triclinium of the House of Peristeria, and that room is defined as a male. Wiseman, Mano - Zissi, 399 think that Peristeria is a male name, but later discuss the same conclusion with caution.

${ }^{8}$ The symbolism of the parties is associated with both groups of antagonistic principles: masculinity, activity, day, divinity and the future associated with the right side, or south; and femininity, passivity, night and past connected to the left, that is, north. (Chevallier, Gheerbrant, 115/116)

${ }^{9}$ The fifth century was a time of great turmoil and culmination of many of the early Christian sects, a century before the appearance of Justinian's "solid hand" and his law on the Chalcedonian religion. Gnosticism and its schools cause the most controversy over the treatment of women in their ranks: from the fact that Gnostic teachings are "ultimately misogynistic to the extreme" (see Perkins, 2002, 2005; King, 2000; Burger, 2005, etc.) to the one that the basic principle of Gnosticism that everything of material nature is imperfect, actually minimizes gender segregateon; allowing for greater involvement of women in learning and liturgy (Pagels, 1979; 1988; 2003).
} 
only a practical answer to the imagined arrangement in this part of the basilica, for now remain open. There are also cases where women who have emphasized their asceticism and commitment to Christianity received the status of honoured men because they eliminated the physical and social characteristics that made them inferior ${ }^{10}$.

The last mosaic with a vowel inscription is located in the diaconicon of the South Basilica at the site Plaoshnik. In the middle part of the room, surrounded by a shield of black and white triangles, there is a four-edged inscription in a circular field, complemented by two ivy leaves in the lower zone.

\section{YIEPMN

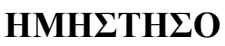

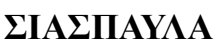

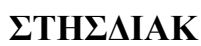 O NOY}

\section{As a conclusion}

The position of the woman in Late Antique society, in general, whether we are talking about Athens, Rome or Judea; was second degree and subordinate. The greatest female virtues, modesty, fidelity and dedication to the home were considered, and every public work or commitment was strictly reserved for the male population. The involvement of women in the public or political life in Late Antique society can hardly be cited through several single examples. This relationship drastically changes with the appearance of Christianity. Namely, as we learn from the texts of the Evangelists and Apostle Paul of the New Testament, women were among Jesus' first followers, they were equal target group of his sermons, and on several occasions played a first-rate role in the key events in the Gospels (the recognition of Martha, around the Cross, the Myrrh-bearer of the Grave).

The two dedicatory inscriptions in mosaic fields, found in the southern nave of the Episcopal Basilica in Stobi, devoted to the "dearest deaconess" who, because of the covenant of the matron, paved the exedra with a mosaic; and Peristeria, as well as that of the deaconess Sosia Paula of Lychnidos; throw a new lightning on the position of women in the church organization from the middle of the 5th century ${ }^{12}$. The covenant in-

\footnotetext{
${ }^{10}$ Cloke, 1995; as is the case with the martyr Perpetua.

${ }^{11}$ Filippova, S., Examples of Early Byzantine Plastics and Capitals from Macedonia with applied inscriptions / or letters, SYSTATIS 7, p. n. 5 http://www.systasis.org.mk/arhiva.asp

${ }^{12}$ The church act of the deaconesses appears in early Christian documents: Acts of the Council of Nicea, where their clerical placement is explained; Olimpia, one of the close collaborators and supporters of Archbishop John Chrysostom, was known as a rich and powerful deaconess in the 5th century. (Karras, 272-316). The deaconesses also had liturgical and preaching functions: pre-
} 
scription of the "dearest deacon" testifies to the still developed and active female clergy who maintained uninterrupted ties with the municipal elite (matron, in this case) who practiced the new religion. On the other hand, if we assume that the three mentioned persons (including also Peristeria here with a precautionary note) are women, impresses the fact that the inscriptions are located in the southern nave of the Basilica, a space so clearly characterized by all church canons as "male". In the present level of research, it is premature to insinuate any connection with the existence of other "unorthodox" teachings in the city itself. Perhaps the layout of the mosaics in front of the eyes of men during the liturgy was a way to leave a memory mark for the transient, but still sufficient, power of the mosaic commissioners.

paring the catechumens, assisting in the baptism of women, and introducing women to the church. However, by the end of the 5th century, in the West they already lost their function, while in the Eastern Church they survive until the 7th century. (Olsen, 22, 25, 27, 29, 41, 53, 58, 60, 70). 


\section{References}

\section{Ancient sources}

Aristotle (1999). Politics 1, 2. Kitchener: Batoche Books.

Demosthenes (1992). Apollodoros against Neaira: (Demosthenes) 59. Warminster, England: Aris \& Phillips.

Flavius Josephus (1892). Flavii Iosephi opera, ed. B. Niese, Berlin: Weidmann.

Homer (1961). Odiseja. Zagreb: Matica hrvatska.

Plato (1956). The Republic. New York: Oxford University Press.

Xenophon (1943). Within The Home. The Greek Reader. NY: Doubleday.

\section{Secondary sources}

Beauchamp, B. J. (1976). Le vocabulaire de la faiblesse feminine dans les textes juridiques romains du troisieme et quatrieme siècle. Revue historique du droit francais et etranger. 54

Burger, G. C. (2005). The Gnostic View of the Feminine. New Media Ministries.

Buzov, M. (1990) Prilog poznavanju osobnih imena sa mozaičkih natpisa u Jugoslaviji. Prilozi 7 (Zagreb)

Chevallier, J. et Gheerbrant, A. (1983). Rječnik simbola. Zagreb: Nakladni zavod Matice hrvatske.

Cloke, G. (1995). This Female Man of God: Women and Spiritual Power in the Patristic Age, $A D$ 350-450. London: Routledge.

Fraschetti, A. (2001). Roman Women. Chicago \& London: University of Chicago Press.

Hengel, M. (1963). Maria Magdalena und die Frauen als Zeugen. Abraham unser Vater. Leiden/Köln: Brill.

Karras, V. A. (2004). Female Deacons in the Byzantine Church. Church History 73.

King, K. L. (2000). Images of the Feminine in Gnosticism. Philadelphia: Fortress Press.

Olsen, J. E. (1992). One ministry many roles: deacons and deaconesses through the centuries. Concordia scholarship today. St Louis: Concordia Publishing House.

Pagels, E. (1979). The Gnostic Gospels. New York: Vintage Books.

Pagels, E. (1988). Adam, Eve and the Serpent. New York: Vintage Books.

Pagels, E. (2003). Beyond Belief: The Secret Gospel of Thomas. New York: Vintage Books.

Perkins, P. (2005). "A Gnostic Gospel? Title and Genre in the Nag Hammadi Collection," ARC. Special Issue: Festschrift for Frederik Wisse. Montreal: McGill University.

Perkins, P. (2002). Gnosticism and the Christian Bible, in Lee M. McDonald and Peter W. Flint (eds.). The Canon Debate. Peabody, MA: Hendrickson, pp. 355-71.

Pomeroy, S. (1984). Women in Helenistic Egypt, From Alexander to Cleopatra. New York: 
Schocken Book.

Rawson, B. (ed.) (1986). The Family in ancient Rome: new perspectives. New York: Cornel University Press.

Rendić - Miočević, D. (1985). Od prvih početaka do kraja antičkog razdoblja, Katalog izložbe. Zagreb: Pisana riječ u Hrvatskoj.

Whiterington III, B. (1984). Women in the Ministry of Jesus. Cambridge: Cambridge University Press.

Wiseman, J., Mano - Zissi, Dj. (1971). Excavations at Stobi, 1970, AJA 75, no.4.

Wiseman, J., Mano - Zissi, Dj. (1973). Excavations at Stobi, 1972, AJA 77, no. 4.

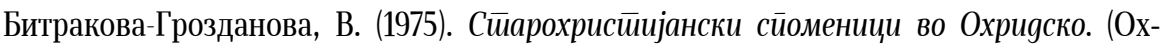
рид).

Василкова-Мидоска, А. (2007). Античките мотиви на мозаиците во Стоби - патишта, влијанија, релации (магистерски труд одбранет на Филозофски Факултет, Скопје).

Јанакиевски, Т. (1980). Мозаикот на подот во централниот брод на ранохристијанската базилика кај локалитетот “Суви Ливади”, с. Доленци - Битола, Майеријали XVIII. (Београд).

Самарџић, П. (2007). Жена у свейлу Библије и библијскоі времена. Београд - Требиње: Епархија Захумско - Херцеговачка и Приморска.

Свето писмо (Библија) (2007). Стариот и Новиот завет (прев. Санде Тодоровски).

Филипова, С. Примери на рановизантиски пластика и капители од Македонија со аплицирани натписи/или букви. SYSTASIS 7 http://www.systasis.org.mk/arhiva.asp

Цветковић - Томашевић, Г. (1978). Рановизанӣијски ӣоgни мозаици: Дарgанија, Макеgонија, Нови Ейир. Београд: Филозофски факултет у Београду, Институт за историју уметности. 